\title{
PERAN SENTRAL WASIT DAN JURI DALAM PENYELENGGARAAN PON XX DI PAPUA
}

\author{
Muhammad Iqbal Jauhar Hanim, S.Pd., M.Or. ${ }^{31}$ \\ (Universitas Negeri Yogyakarta)

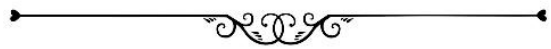

“Sebagai atlet yang sportif, maka sudah seharusnya dapat menghormati penilaian juri dan keputusan wasit selama dan sesudah pertandingan"

Dekan Olahraga Nasional (PON) merupakan kompetisi perwakilan atlet dan ofisial tim dari setiap provinsi dan diselenggarakan setiap 4 tahun sekali. Pada tahun ini merupakan edisi PON yang ke-20 dilangsungkan di Provinsi Papua dengan slogan "Torang Bisa", yang bermakna kita bisa, diucapkan untuk menambah semangat juang para atlet. PON XX di Papua diselenggarakan mulai tanggal 02 Oktober 2021 sampai dengan 15 Oktober 2021. Namun sejumlah cabang olahraga telah mengawali pertandingan sebelum pembukaan. Stadion Lukas Enembe menjadi lokasi utama penyelenggaraan event olahraga nasional ini, terutama dalam upacara pembukaan dan penutupan. Gelaran olahraga nasional ini mulanya direncanakan untuk dilaksanakan pada tahun 2020, namun ditunda karena Pandemi Covid-19. Ini

\footnotetext{
${ }^{31}$ Penulis lahir di Mojokerto, 05 Maret 1993, penulis merupakan fresh graduate S2 Ilmu Keolahragaan di Universitas Negeri Yogyakarta. Penulis menyelesaikan gelar Sarjana Pendidikan Jasmani dan Keolahragaan di Universitas Negeri Malang (2015), sedangkan gelar Magister Ilmu Keolahragaan diselesaikan di Universitas Negeri Yogyakarta (2020).
} 
merupakan pertama kalinya Provinsi Papua ditunjuk menjadi tuan rumah dalam perhelatan Pekan Olahraga Nasional. Pada PON XX ini, Provinsi Jawa Barat keluar sebagai juara umum dengan jumlah perolehan medali sebanyak 353 medali, terdiri dari 133 medali emas, 105 medali perak, dan 115 medali perunggu.

Kesuksesan penyelenggaraan PON tidak terlepas dari kinerja profesional dan objektivitas wasit dan juri dalam pertandingan. Wasit dan perangkat pertandingan yang bertugas pada PON XX di Papua sudah mendapatkan Surat Keputusan dari KONI tingkat provinsi. Wasit dan juri merupakan perangkat pertandingan yang memiliki kewenangan dan hak untuk mengambil keputusan selama memimpin pertandingan. Oleh karena perannya yang krusial, ia dituntut memiliki pengetahuan tentang peraturan permainan, kecakapan memimpin pertandingan, ketegasan dalam menerapkan peraturan permainan dan adil, serta memiliki fisik yang prima dan gerak tubuh yang lincah.

Menurut Kamus Besar Bahasa Indonesia, wasit dapat diartikan sebagai (1) pemisah, pelerai, dan pendamai, (2) penengah, (3) perantara, (4) penentu, dan (5) pemimpin. Sedangkan dalam Bahasa Inggris, wasit disebut dengan referee, umpire, judge, dan linesman. Menurut Herdiansyah dan Nurasyifa (2020) wasit memiliki wewenang mengatur berlangsungnya pertandingan olahraga. Dalam kompetisi olahraga, peran wasit sangat penting dalam menilai kinerja atlet, sebagai dasar untuk menentukan atlet yang berhak melaju ke babak selanjutnya dan menjadi juara. Tugas utama wasit yaitu memimpin pertandingan agar berjalan lancar tanpa ada gangguan. Untuk itu diperlukan ketegasan dan konsistensi dalam menerapkan peraturan permainan.

Seorang wasit hendaknya memiliki pengetahuan yang cukup tentang peraturan permainan. Kinerja wasit dapat ditunjang dengan memiliki tingkat kesegaran jasmani yang baik, serta terbebas dari penyakit. Hal tersebut dapat diupayakan dengan cara berlatih fisik dengan rutin, 
pengaturan pola makan bergizi dan bernutrisi, serta pola istirahat yang teratur. Membahas kinerja wasit di lapangan, tidak dapat dipisahkan dari wibawa yang harus dimilikinya. Beberapa indikator wibawa wasit seperti (1) memiliki sikap dan kepribadian yang baik, (2) memiliki integritas dan sikap yang tegas, (3) berpakaian yang sopan dan sesuai dengan situasi pertandingan, (4) cakap dan dalam melaksanakan tugas.

Menurut Kamus Besar Bahasa Indonesia, juri dapat diartikan sebagai (1) seorang panitia yang menilai dan memutuskan pihak yang menang dan kalah, (2) orang yang menilai benar atau salah. Kehadiran juri di lapangan berperan sebagai pengawas pertandingan. Pada tahun 2018, Menteri Pemuda dan Olahraga, Imam Nahrowi, telah mewajibkan pelatih, wasit, dan juri agar mengikuti pelatihan dan memiliki lisensi demi mendukung profesionalitas kerja. Sebagai upaya untuk menghasilkan juri yang profesional, beberapa organisasi olahraga nasional telah memantau dan mengikutkan pelatihan bagi juri untuk kemudian dapat mendapatkan sertifikat dan lisensi dengan standar internasional. Setiap dua tahun sekali, lisensi juri akan diganti dengan yang baru, sehingga diharapkan objektivitas penilaian juri lebih dominan dibandingkan dengan subjektivitasnya.

Beberapa cabang olahraga yang melibatkan juri diantaranya yaitu renang indah, pencak silat, tinju, gulat, atletik, dan sebagainya. Dalam satu cabang olahraga terdapat beberapa orang juri yang mengemban tugas dan tanggung jawab yang berbeda, seperti misalnya pada cabang olahraga lari, yang terdiri dari 1) starter, yang bertugas memberangkatkan pelari, (2) recall starter, yang bertugas mengecek dan melakukan absensi kepada pelari, (3) timer, yang bertugas mencatat waktu, (4) pengawas lintasan, yang bertugas berdiri pada titik/tempat tertentu untuk mengawasi pelari apabila melakukan kesalahan dan pelanggaran, (5) juri kedatangan, yang bertugas mencatat kedatangan pelari pertama sampai pelari terakhir, dan (6) juri pencatat hasil, 
yang bertugas melakukan perangkingan dan menentukan urutan juara lari.

Dalam pertandingan yang sengit dan tensi persaingan yang tinggi, atlet dan ofisial tim dimungkinkan untuk melakukan protes kepada wasit dan juri. Terlebih apabila keputusan tersebut dinilai merugikan tim dan berlawanan dengan bukti rekaman dari ofisial tim. Protes dan keberatan dapat dilakukan dengan cara yang baik. Berikut ini merupakan catatan protes terhadap juri dan wasit PON XX di Papua yang dirangkum dari pemberitaan media cetak dan elektronik, seperti:

\section{Cabang Olahraga Gulat Putra, Protes dilakukan Kontingen Papua}

Kericuhan terjadi karena protes dari pelatih Papua saat pertarungan masih berlangsung. Kubu tuan rumah menganggap terjadi kesalahan penilaian oleh dewan juri. Ketika itu skor imbang 2-2. Protes itu direspon oleh wasit dan juri untuk dilakukan pengecekan dan koordinasi. Keputusan akhir juri yaitu memberikan tambahan skor 1 bagi atlet Kalimantan Selatan.

\section{Cabang Olahraga Muaythai, Protes dilakukan Kontingen Banten}

Tim Muaythai Banten mengajukan protes kepada juri Muaythai. Hal tersebut dikarenakan atlet Muaythai Banten dinyatakan kalah atas atlet Papua. Padahal selama 3 ronde atlet Banten diyakini unggul atas lawannya. Klaim tersebut dibuktikan dengan video rekaman dari tim Muaythai Banten. Persoalan ini selanjutnya dibahas didepan dewan hakim.

\section{Cabang Olahraga Senam Aerobik, Protes dilakukan Kontingen Papua}

Kontingen Papua, melalui pelatih kepala, mengajukan protes kepada juri setelah pengumuman hasil akhir senam aerobik. Namun sikap juri tidak bersedia mendengarkan protes tersebut dan memilih meninggalkan arena 
pertandingan. Sikap juri dinilai tidak menghargai Papua sebagai tuan rumah.

\section{Cabang Olahraga Angkat Berat, Protes dilakukan Kontingen Lampung}

Atlet angkat berat Lampung mengajukan protes kepada tiga orang wasit. Protes disebabkan pada angkatan pertama dalam babak dead lift ia dinyatakan gagal dan dianulir oleh wasit. Wasit memutuskan gagal secara gerakan. Protes tersebut tidak mengubah pendirian wasit pertandingan dilanjutkan.

\section{Cabang Olahraga Tinju, Protes dilakukan Kontingen Papua Barat}

Kericuhan kecil terjadi pada pertandingan tinju wanita yang mempertemukan Papua melawan Papua Barat. Insiden ini terjadi setelah wasit dan juri menyatakan kubu tuan rumah, Papua yang memenangkan pertandingan. Kontingen Papua Barat selanjutnya mengajukan protes keras kepada wasit dan juri. Panitia pertandingan meninjau ulang keputusan tersebut berdasarkan rekaman lambat.

\section{Cabang Olahraga Pencak Silat, Protes dilakukan Kontingen Sulawesi Selatan}

Atlet pencak silat Sulawesi Selatan tertendang kemaluannya saat bertanding melawan atlet Papua. Insiden ini memicu protes keras dari Kontingen Sulawesi Selatan kepada wasit dan juri karena merasa dicurangi dan tidak adil. Pertandingan sempat terhenti selama 20 menit sebelum akhirnya atlet tuan rumah, Papua dinyatakan menang teknik.

\section{Cabang Olahraga Terjun Payung, Protes dilakukan Kontingen Kalimantan Timur}

Atlet terjun payung Kalimantan Timur mengajukan protes keras kepada dewan juri dan hakim pertandingan, karena diputuskan atlet Papua Barat yang meraih emas dalam cabang olahraga terjun payung. Padahal sebelumnya hakim dan juri menyatakan ada juara bersama, sehingga 
keduanya mendapatkan emas. Keputusan juri dan wasit didasarkan atas sikap dari atlet Kalimantan Timur yang menolak melakukan tanding ulang untuk menentukan raihan emas dan perak.

\section{Cabang Olahraga Tinju Putra, Protes dilakukan Kontingen DKI Jakarta}

Pertandingan tinju antara atlet DKI Jakarta melawan atlet Nusa Tenggara Timur berakhir ricuh. Atlet DKI Jakarta merasa tidak puas terhadap keputusan wasit dan juri. Kemudian ia melampiaskan kemarahannya dengan membanting pintu dan merusak spanduk. Tindakan terebut menjadi pemicu kemarahan relawan dan panitia pelaksana pertandingan. Berdasarkan video yang beredar, terlihat relawan dan panitia pelaksana pertandingan mengejar, mencaci, dan menyerang atlet tinju DKI Jakarta sampai keluar arena.

Wasit dan juri mengambil posisi sebagai penengah, yang diharapkan mampu mengambil keputusan yang jujur, adil, dan tidak memihak. Ketegasan juga diperlukan wasit dalam menghadapi protes dari pelatih, atlet, dan ofisial tim. Namun wasit juga manusia yang dapat melakukan kesalahan. Untuk itulah diperlukan bantuan dari asisten wasit/juri, sehingga diperoleh masukan dan koreksi apabila terjadi keraguan terhadap hasil pengamatan di lapangan. Panitia pertandingan dapat memasang kamera untuk merekam pertandingan, sehingga diperoleh tayangan lambat yang berguna sebagai dasar untuk mengambil keputusan dan bukti dalam menanggapi protes dari atlet. Juri memberikan penilaian dan wasit memutuskan hasil pertandingan setelah melihat video lambat.

Sebagai atlet yang sportif, maka sudah seharusnya dapat menghormati penilaian juri dan keputusan wasit selama dan sesudah pertandingan. Protes merupakan hal yang wajar apabila dilakukan dengan etika dan sesuai dengan peraturan pertandingan. Protes secara berlebihan seperti membanting pintu dan merusak sarana olahraga justru merugikan tim. 
Sebagai refleksi dari penyelenggaraan PON XX di Papua, saran yang dapat diberikan penulis bagi juri dan wasit yaitu apabila mendapatkan keberatan, protes, dan masukan dari atlet dan ofisial tim, maka sebaiknya dapat ditampung terlebih dahulu. Sedangkan untuk memutuskan penilaian dan hasil pertandingan dapat diberikan kemudian. Apabila juri dan wasit tidak bersedia menerima keberatan dari atlet dan ofisial tim, maka hal tersebut juga tidak dapat dibenarkan berdasarkan pada mekanisme pelaksanaan pertandingan. Terlepas dari itu semua, kinerja dan usaha wasit dan juri untuk menegakkan sportivitas melalui pertandingan yang fair play selama pelaksanaan PON XX di Papua patut diapresiasi dan dihargai. 